\title{
EFFECTS OF SUPPLEMENTING RABBIT DIETS WITH MORINGA OLEIFERA DRY LEAVES AT DIFFERENT LEVELS ON THEIR PRODUCTIVE PERFORMANCE
}

\author{
M.E. Omara; Ghada S. El-Esawy; W.A. Riad and A.M.A. Mohi El-Din \\ Animal Production Research Institute, Agriculture Research Center, Dokki, Giza.
}

(Received 29/4/2018, accepted 7/6 /2018)

\section{SUMMARY}

$\mathrm{F}$ orty growing male New Zealand White (NZW) rabbits at 7 weeks of age with average live body weight of $772 \pm 8 \mathrm{~g}$ were chosen and used in a complete randomized design of four treatments (10 in each) for 12 weeks feeding period. Rabbits in the $1^{\text {st }}$ group were fed Commercial Rabbit Diet (CRD) without supplement (control, T1). While, in the $2^{\text {nd }}, 3^{\text {rd }}$ and $4^{\text {th }}$ groups, diets contained 5.48, 10.97 and $16.45 \%$ Moringa oleifera Dry Leaves (MDL) to cover 10, 20 and 30\% from protein content of CRD for T2, T3 and T4; respectively. Results showed higher CP and EE contents, but NFE content was lower in MDL in compared with CRD. The contents of DM, OM, CF and ash were similar among treatments. The digestibility coefficients of OM, CP, EE and NFE and feeding values as TDN, DCP and DE increased significantly $(\mathrm{P}<0.05)$ with increasing levels of MDL. Dry matter content of the cecal digesta was significantly higher $(\mathrm{P}<0.05)$ in $\mathrm{T} 4$ (30\% MDL) than T1 (control), however, cecal pH value revealed inverse trend. The concentrations of TVFA's and $\mathrm{NH}_{3}-\mathrm{N}$ in cecal digesta increased significantly $(\mathrm{P}<0.05)$ with increasing levels of MDL in diets. The concentrations of total protein, albumin and globulin increased significantly $(\mathrm{P}<0.05)$, however cholesterol concentration decreased significantly $(\mathrm{P}<0.05)$ with increasing levels of MDL. The intake of total DM and CP decreased significantly $(\mathrm{P}<0.05)$ with increasing levels of MDL. Average daily intake of TDN, DCP and DE were significantly highest $(\mathrm{P}<0.05)$ in $\mathrm{T} 1$ and $\mathrm{T} 2$. Final body weight, total and daily weight gain and growth performance index $(\mathrm{GPI})$ increased significantly $(\mathrm{P}<0.05)$ with increasing levels of MDL. The amounts of DM, TDN, CP, DCP and DE required for producing one kg weight gain decreased significantly $(\mathrm{P}<0.05)$ with increasing levels of MDL. Total feed cost and price of total weight gain increased significantly $(\mathrm{P}<0.05)$ with increasing MDL. Feed cost per kg gain was significantly $(\mathrm{P}<0.05)$ higher in $\mathrm{T} 4$ compared to $\mathrm{T} 1$. Slaughter and carcass weights and dressing percentage increased significantly $(\mathrm{P}<0.05)$, but abdominal fat weight and the content of ether extract decreased significantly $(\mathrm{P}<0.05)$ with increasing the level of MDL supplementation compared with control. Results revealed that, it can be use moringa dry leaves with rate of $16>45 \%$ as a source of protein in growing rabbit diet. This level tended to increase digestibility coefficients, feeding values, improved feed and economical efficiencies. Moreover, dressing percentage and edible meat increased.

Keywords: Rabbits, Moringa oleifera dry leaves, digestibility, blood biochemical, growth performance, carcass traits.

\section{INTRODUCTION}

Several biological properties ascribed to various parts of Moringa tree, the leaves have been reported to be a valuable source of carotene (precursor of vit. A), vitamins (B-complex, C, D and K) beside some important macro-elements as calcium, potassium, zinc, iron, copper and selenium (Dorga et al., 1975 and Booth and Wickens, 1988). Moreover, Moringa oleifera leaves and fruits prevent effectively morphological changes and oxidative damage in human and animals by enhancing the activities of antioxidant enzymes, reducing the intensity of lipid peroxidation and inhibiting generation of free radicals (Sreelather and Padma, 2009 and Osman et al., 2012). It was also used to promote the immune system against infections (Jaiswall et $a l ., 2009$ ) and its extracts have positive effects on hematological parameters of rabbits (Chinwe and Isitua, 2010). The chemical composition of Moringa leave meal has been investigated by many workers, the results differ for crude protein, crude fiber, ether extract, ash, acid detergent lignin, macro and micro-elements (Moyo et al., 2011, Kakengi et al., 2003 and Oduro et al., 2008). The differences in chemical constituents is 


\section{Omara et al.}

related to type of soil, irrigated-water quality, ambient temperature and relative humidity, plant age, stage of maturity and the way in which leaves are collected, dried and sieved (Moyo et al., 2011 and Onu and Aniebo, 2011).

In Egypt, great attention has been given by plant breeders to implant Moringa oleifera imported seeds in agricultural and newly reclaimed lands for human and animal uses. Limited studies have been conducted on lactating cattle, laying hens and rabbits, with either fresh (green fodder) or dry leaves. Moringa dry leaves supplementation may play a role as growth enhancer for rabbits when fed at maximum $30 \%$ of the daily ration (El-Badawi et al., 2014). Moringa oliefera leaves is a potential plant protein supplement and could be included in the diet to substitute $40 \%$ of the concentrate feed mixture protein. Improved digestibility, rumen fermentation, milk yield and composition were reported in lactating Friesian cows (El-Esawy, 2015).

Therefore, the objective of this study was to investigate the effect of using different levels of Moringa oleifera dry leaves as a source of protein on digestibility, blood parameters, growth performance, feed conversion ratio and economic efficiency of growing New Zealand white rabbits, besides the carcass traits were studed.

\section{MATERIALS AND METHODS}

\section{Experimental rabbits and diets:}

Forty growing male New Zealand White (NZW) rabbits at 7 weeks of age with average live body weight of $772 \pm 8 \mathrm{~g}$ were used in a complete randomized design. Rabbits were assigned in four groups to receive four treatments (10 in each). Feeding trial lasted 12 weeks as a feeding period. Rabbits in the $1^{\text {st }}$ group were fed commercial rabbit diet (CRD) without supplement (control, T1). While, those of the $2^{\text {nd }}$, $3^{\text {rd }}$ and $4^{\text {th }}$ groups, fed diets contained 5.48, 10.97 and $16.45 \%$ Moringa oleifera dry leaves (MDL), respectively. Protein amounts of MDL were represents as 10, 20 and 30\% of the protein content of CRD for T2, T3 and T4, respectively. Rabbits in all groups were fed to cover their requirements according to NRC (1977). Ingredients used in formulation of the tested diets are shown in Table (1).

Table (1): Formulation (\%) of experimental rations.

\begin{tabular}{lcccc}
\hline Ingredient & $\mathrm{T} 1$ & $\mathrm{~T} 2$ & $\mathrm{~T} 3$ & $\mathrm{~T} 4$ \\
\hline Soybean meal 44\% & 17.00 & 14.45 & 11.90 & 9.37 \\
Wheat bran & 19.50 & 18.00 & 16.70 & 14.78 \\
Yellow corn grain & 28.00 & 27.80 & 27.50 & 27.55 \\
Berseem hay & 30.00 & 28.77 & 27.43 & 26.35 \\
Moringa dry leaves & 0.00 & 5.48 & 10.97 & 16.45 \\
Molasses & 2.00 & 2.00 & 2.00 & 2.00 \\
Limestone & 1.00 & 1.00 & 1.00 & 1.00 \\
Common salt & 1.00 & 1.00 & 1.00 & 1.00 \\
Premix* & 0.50 & 0.50 & 0.50 & 0.50 \\
Dicalcium phosphate & 1.00 & 1.00 & 1.00 & 1.00 \\
Total & 100 & 100 & 100 & 100 \\
\hline
\end{tabular}

* Each one kg of premix (minerals and vitamins mixture) contains vit. A, 20000 IU; vit. D3, 15000 IU; vit. E, 8.33 g; vit. $K, 0.33 \mathrm{~g} ;$ vit. B1, 0.33; vit. B2, $1.0 \mathrm{~g}$; vit. B6, $0.33 \mathrm{~g}$; vit. B5, $8.33 \mathrm{~g}$; vit. B12, $1.7 \mathrm{mg}$; pantothenic acid, $3.33 \mathrm{~g}$; biotine, $33 \mathrm{mg}$; folic acid, $0.83 \mathrm{~g}$; choline chloride, $200 \mathrm{mg}$.

$T 1=$ Control,$T 2=5.48 \%$ Moringa oleifera dry leaves, $T 3=10.97 \%$ Moringa oleifera dry leaves and $T 4=16.45 \%$ Moringa oleifera dry leaves.

\section{Housing and management:}

Rabbits were housed individually in galvanized wire cages $(40 \times 50 \times 60 \mathrm{~cm})$ and fresh water was automatically available ad-libitum. All rabbits were kept under the same managerial, hygienic and environmental conditions. 


\section{Experimental procedures:}

Live body weight and feed intake were recorded weekly throughout the experimental feeding period. Then, daily weight gain, feed conversion ratio and economic efficiency were calculated. Also, growth performance index (GPI) was calculated according to North (1981) as given below:

$$
\text { GPI }=[\text { final body weight }(\mathrm{kg}) / \text { feed conversion ratio }] \times 100
$$

\section{Digestibility trials:}

Digestibility trials were undertaken at termination of the experiment (18 weeks of age) using three animals from each group. Rabbits were housed individually in metabolic cages. The experimental diets were offered daily and fresh water was provided ad-libitum. Feed intake was determined and feces were collected for 5 days as a collection period. Feces of each animal was mixed, dried at $60{ }^{\circ} \mathrm{C}$ for 24 hours, then representative samples were ground for chemical analysis. Chemical analysis of the 4 experimental diets and feces was determined according to AOAC (1995). Then nutritive values as TDN, DCP and DE were calculated for the experimental diets.

\section{Slaughter technique:}

After termination of the feeding experiment, three representative rabbits (randomly chosen from each group) were fasted for $12 \mathrm{hrs,} \mathrm{weighed} \mathrm{and} \mathrm{handly} \mathrm{slaughtered.} \mathrm{After} \mathrm{complete} \mathrm{bleeding,} \mathrm{the} \mathrm{drained} \mathrm{blood}$ was collected and weighed. Slaughtered animals were de-skinned, dressed out and the hot carcass was weighed and recorded. Edible offals (liver, heart, spleen and kidneys), non-edible offals (lungs, clean empty gastrointestinal tract and testicles) and trimmings (skin, four legs, blood and gastrointestinal tract contents) were separately weighed and recorded.

\section{Cecal contents samples:}

Cecal contents of slaughtered rabbits were taken for determining of $\mathrm{pH}$ using Bechman $\mathrm{pH}$ meter. However, samples from cecal contents were taken to determins of $\mathrm{NH}_{3}-\mathrm{N}$ concentration according to the method of AOAC (1995) and TVFA's concentration according to Warner (1964).

\section{Blood sampling:}

At the end of experimental period, blood was collected from sacrificed rabbits ( 3 animals in each group) in clean sterile tubes for each animal immediately after slaughtering. Blood samples were collected in heparinized tubes and centrifuged at $3500 \mathrm{rpm}$ for 15 minutes and then plasma was separated and stored at $-20{ }^{\circ} \mathrm{C}$ till biochemical analysis. Total proteins, albumin and cholesterol concentrations as well as activities of Aspartate (AST) and Alanine (ALT) amino acids transferases were determined using spectrophotometer (Spectronic 21 DUSA) and commercial diagnostic kits (Combination, Pasteur Lap.). Globulin concentration was obtained by difference (total protein - albumin).

\section{Statistical analysis:}

Data were statistically analyzed using general linear models (GLM) procedures adapted by IBM SPSS Statistics (2014) for user's guide with One-way ANOVA. Duncan test within SPSS program was done to determine the degree of significance among means as recorded with Duncan (1955).

\section{RESULTS AND DISCUSSIONS}

\section{Chemical composition of MDL and experimental diets:}

Table (2) showed that moringa dry leaves (MDL) was high CP and EE contents and mediate in CF and NFE contents, which were nearly similar to values obtained by El-Esawy (2015). Calculated composition of tested diets was nearly similar for the different diets and cover the requirements of growing rabbits (NRC, 1977).

\section{Nutrients digestibility and nutritive values:}

Data in Table (3) showed that the digestibility of OM and NFE and the contents of TDN and DE significantly $(\mathrm{P}<0.05)$ increased with increasing levels of MDL recording 77.89, 82.34, 72.88\% and 3213 $\mathrm{Kcal} / \mathrm{kg} \mathrm{DM}$; respectively. All previous figures observed with T3. The digestibility of CP and EE and DCP 


\section{Omara et al.}

percentages were significantly higher $(\mathrm{P}<0.05)$ in diets supplemented with MDL than the CRD and the highest values were found with $30 \% \operatorname{MDL}$ (76.17, 73.90 and $12.68 \%$; respectively). No significant effect was observed on digestibility of CF between un-supplemented or MDL supplemented diets. The improvement of digestibility might hold true that, moringa dry leaves in a powder form could have some digestion promoting effects. These results agreed with those obtained by El-Badawi et al. (2014), who reported that feeding rabbits on rations contained MDL up to $0.30 \%$ was associated with significant $(\mathrm{P}<0.05)$ increases of nutrients digestibility. El-Esawy (2015), found that introducing moringa oleifera plant in rations of lactating Friesian cows resulted in significant increase in the digestibility and nutritive values of the rations with the best results at level of $40 \% \mathrm{MOL}$.

Table (2): Proximate chemical composition of MDL and experimental rations.

\begin{tabular}{|c|c|c|c|c|c|}
\hline \multirow{2}{*}{ Item } & \multirow{2}{*}{ MDL } & \multicolumn{4}{|c|}{ Experimental ration } \\
\hline & & $\mathrm{T} 1$ & $\mathrm{~T} 2$ & T3 & $\mathrm{T} 4$ \\
\hline DM \% & 88.98 & 87.22 & 87.13 & 87.41 & 87.50 \\
\hline \multicolumn{6}{|c|}{ Composition of DM \% } \\
\hline $\mathrm{OM}$ & 89.88 & 90.29 & 90.27 & 90.25 & 90.22 \\
\hline $\mathrm{CP}$ & 29.60 & 16.23 & 16.37 & 16.51 & 16.65 \\
\hline $\mathrm{CF}$ & 11.24 & 12.55 & 12.54 & 12.52 & 12.51 \\
\hline $\mathrm{EE}$ & 3.90 & 2.67 & 2.68 & 2.70 & 2.71 \\
\hline NFE & 45.14 & 58.84 & 58.68 & 58.52 & 58.35 \\
\hline Ash & 10.12 & 9.71 & 9.73 & 9.75 & 9.78 \\
\hline
\end{tabular}

Table (3): Nutrients digestibility and nutritive values of experimental rations.

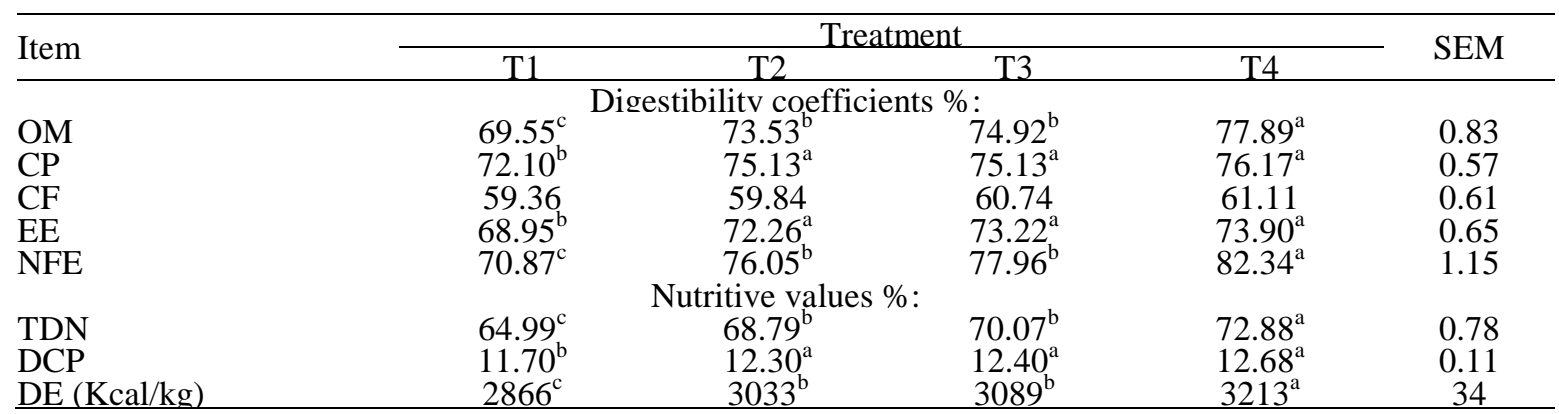

$a, b, c$ : Values in the same row with different superscripts differ significantly $(P<0.05)$.

DE $(\mathrm{Kcal} / \mathrm{kg})=T D N \% \times 44.09$ (May and Bell, 1971).

$T 1=$ Control,$T 2=5.48 \%$ Moringa oleifera dry leaves, $T 3=10.97 \%$ Moringa oleifera dry leaves and $T 4=16.45 \%$

Moringa oleifera dry leaves.

\section{Cecal fermentation activity:}

Results in Table (4) revealed that DM content of the cecal digesta was significantly $(\mathrm{P}<0.05)$ higher in all diets containing MDL than $\mathrm{T} 1$ (control). Whereas, cecal $\mathrm{pH}$ value was significantly $(\mathrm{P}<0.05)$ lower in $\mathrm{T} 4$ (30\% MDL) than T1 (control), where that of T2 and T3 was intermediate between them with insignificant differences. Concentrations of TVFA's and $\mathrm{NH}_{3}-\mathrm{N}$ in cecal digesta significantly $(\mathrm{P}<0.05)$ increased with increasing the level of MDL in diet, without significant differences between T3 and T4. Results obtained here indicated inverse relationship between $\mathrm{pH}$ value and the concentration of total VFA's $(\mathrm{r}=-0.91)$. The increase concentrations of TVFA's and $\mathrm{NH}_{3}-\mathrm{N}$ in cecal digesta confirmed with the increase of digestibility of NFE and CP obtained in Table (3). The increase of $\mathrm{NH}_{3}-\mathrm{N}$ concentration with increasing the level of MDL might be due to increase degradable protein content. These results agreed with those obtained by Khalel et al. (2014) who found that rumen $\mathrm{pH}$ values and $\mathrm{NH}_{3}-\mathrm{N}$ concentration were lower $(\mathrm{P}<0.05)$ with $40 \%$ Moringa ration than those containing 0 or $20 \%$ Moringa rations, while TVFA's concentration was remarkably higher by nearly 31 and $32 \%$ for 20 and $40 \%$ Moringa rations than $0 \%$ Moringa ration; respectively. El-Esawy (2015) reported that rumen $\mathrm{pH}$ value was lower for cows fed 20 and 40\% Moringa 
rations compared to 0 and $60 \%$ Moringa rations. Ruminal $\mathrm{NH}_{3}-\mathrm{N}$ concentration decreased significantly $(\mathrm{P}<0.05)$ by inclusion of Moringa in the diets, where, TVFA's increased by increasing Moringa level. In addition to, 20 and 40\% Moringa rations recorded the highest value compared to 0\% Moringa ration.

Table (4): Cecal fermentation activity of rabbits fed experimental rations.

\begin{tabular}{|c|c|c|c|c|c|}
\hline \multirow{2}{*}{ Item } & \multicolumn{4}{|c|}{ Treatment } & \multirow{2}{*}{ SEM } \\
\hline & $\mathrm{T} 1$ & $\mathrm{~T} 2$ & T3 & T4 & \\
\hline DM content of digesta $\%$ & $26.22^{b}$ & $28.25^{\mathrm{a}}$ & $28.92^{\mathrm{a}}$ & $28.65^{\mathrm{a}}$ & 0.36 \\
\hline $\mathrm{pH}$ value & $6.80^{\mathrm{a}}$ & $6.67^{\mathrm{ab}}$ & $6.49^{\mathrm{ab}}$ & $6.38^{\mathrm{b}}$ & 0.07 \\
\hline TVFA's (mmol/100 ml) & $33.65^{\mathrm{c}}$ & $36.94^{\mathrm{b}}$ & $39.29^{\mathrm{a}}$ & $41.13^{\mathrm{a}}$ & 0.79 \\
\hline NH3-N (mg/100 ml) & $23.01^{\mathrm{c}}$ & $25.35^{\mathrm{b}}$ & $27.31^{\mathrm{a}}$ & $28.63^{\mathrm{a}}$ & 0.59 \\
\hline
\end{tabular}

$a, b, c$ : Values in the same row with different superscripts differ significantly $(P<0.05)$.

$T 1=$ Control , T2 = 5.48\% Moringa oleifera dry leaves, T3 = 10.97\% Moringa oleifera dry leaves and T4 $=16.45 \%$ Moringa oleifera dry leaves.

\section{Blood parameters:}

The tested rations showed significant $(\mathrm{P}<0.05)$ effects on blood plasma total protein, albumin, globulin and cholesterol concentrations (Table 5). The concentrations of total protein, albumin and globulin increased significantly $(\mathrm{P}<0.05)$, while cholesterol concentration decreased significantly $(\mathrm{P}<0.05)$ with increasing the level of MDL supplement. Whereas, activities of AST and ALT enzymes not significantly affected by MDL supplement. These results agreed with those obtained by Ibrahim et al. (2014) who reported that globulin level was significantly increased in rabbits Tr3 (4 g MPS/kg diet) by $20.50 \%$ as compared to control group. Musa Azara et al. (2014) found that mean value of cholesterol is significantly lower in Moringa olefera seeds treatment group $(\mathrm{P}<0.05)$. El-Esawy (2015) showed significantly increased total protein and its fractions (albumin and globulin) by inclusion Moringa into the diets compared to the control ration. Olatunji et al. (2013) indicated that AST and ALT activity in serum of rabbits were not significantly affected $(\mathrm{P}>0.05)$ by the dietary inclusion of Moringa leaf meal.

Table (5): Biochemical parameters in blood serum of rabbits fed experimental rations.

\begin{tabular}{|c|c|c|c|c|c|}
\hline \multirow{2}{*}{ Item } & \multicolumn{4}{|c|}{ Treatment } & \multirow{2}{*}{ SEM } \\
\hline & $\mathrm{T} 1$ & $\mathrm{~T} 2$ & T3 & T4 & \\
\hline Total proteins (g/dl) & $6.34^{\mathrm{c}}$ & $6.83^{b}$ & $7.30^{\mathrm{a}}$ & $7.75^{\mathrm{a}}$ & 0.15 \\
\hline Albumin (g/dl) & $3.65^{\mathrm{c}}$ & $3.85^{\mathrm{bc}}$ & $4.05^{\mathrm{ab}}$ & $4.30^{\mathrm{a}}$ & 0.08 \\
\hline Globulin (g/dl) & $2.69^{c}$ & $2.98^{\mathrm{bc}}$ & $3.25^{\mathrm{ab}}$ & $3.45^{\mathrm{a}}$ & 0.10 \\
\hline Cholesterol (mg/dl) & $79.80^{\mathrm{a}}$ & $75.60^{\mathrm{b}}$ & $60.00^{\mathrm{d}}$ & $69.76^{\mathrm{c}}$ & 1.96 \\
\hline Activity of AST (IU/ml) & 41.65 & 41.63 & 42.91 & 42.50 & 0.24 \\
\hline Activity of ALT (IU/ml) & 26.68 & 26.31 & 27.20 & 27.93 & 0.38 \\
\hline
\end{tabular}

$a, b, c, d$ : Values in the same row with different superscripts differ significantly $(P<0.05)$.

$T 1=$ Control,$T 2=5.48 \%$ Moringa oleifera dry leaves, $T 3=10.97 \%$ Moringa oleifera dry leaves and $T 4=16.45 \%$ Moringa oleifera dry leaves.

\section{Feed intake:}

The intake of total DM and CP decreased significantly $(\mathrm{P}<0.05)$ with increasing the level of MDL supplement (Table 6). Average DM intake decreased by 5.47, 10.83 and $16.20 \mathrm{~g} /$ day for T2, T3 and T4 compared with $\mathrm{T} 1$; respectively. The corresponding values for $\mathrm{CP}$ were $0.75,1.49$ and $2.26 \mathrm{~g} / \mathrm{day}$; respectively. Average daily intake of TDN, DCP and DE were significantly higher $(\mathrm{P}<0.05)$ for rabbits in T1 and T2 than those in T3 and T4. The intake of TDN decreased by 2.23 and $3.48 \mathrm{~g} /$ day; DCP by 0.61 and $1.02 \mathrm{~g} /$ day and DE by 10 and $16 \mathrm{Kcal} /$ day for T3 and T4 compared with T1; respectively. Generally, using MDL with rate of $16.45 \%$ as a $30 \%$ protein of rations tended to significantly $(\mathrm{P}<0.05)$ decrease in total DM, 


\section{Omara et al.}

TDN, DCP and DE intakes, as shown in Table (6). These results are in agreement with those obtained by Odeyinka et al. (2008) who found that average daily DM intake by rabbits decreased significantly with increasing the level of Moringa oleifera leaves. Safwat et al. (2014) revealed that the highest feed intake values by rabbits were observed by the $40 \%$ Moringa oleifera leaf meal (MOLM) and control groups without any significant difference; meanwhile, the other three groups had the lowest values $(\mathrm{P}<0.05)$, whereas the $30 \%$ Leucaena leucocephala (LLM) group had also the same significant level with the control group.

Table (6): Feed intake (on DM basis) by rabbits in fed experimental rations.

\begin{tabular}{|c|c|c|c|c|c|}
\hline \multirow{2}{*}{ Item } & \multicolumn{4}{|c|}{ Treatment } & \multirow{2}{*}{-SEM } \\
\hline & $\mathrm{T} 1$ & $\mathrm{~T} 2$ & T3 & $\mathrm{T} 4$ & \\
\hline DM \% & 87.22 & 87.13 & 87.41 & 87.50 & \\
\hline DM intake (g/day) & $105.61^{\mathrm{a}}$ & $100.14^{b}$ & $94.78^{\mathrm{c}}$ & $89.41^{\mathrm{d}}$ & 1.55 \\
\hline Feed intake, as fed (g/day) & $121.08^{\mathrm{a}}$ & $114.93^{b}$ & $108.43^{\mathrm{c}}$ & $102.18^{\mathrm{d}}$ & 1.72 \\
\hline $\mathrm{CRD}, \%$ & 100.00 & 94.52 & 89.03 & 83.66 & \\
\hline MDL. $\%$ & 0.00 & 5.48 & 10.97 & 16.45 & \\
\hline TDN (g/day) & $68.64^{\mathrm{a}}$ & $68.89^{\mathrm{a}}$ & $66.41^{\mathrm{b}}$ & $65.16^{\mathrm{b}}$ & 0.49 \\
\hline $\mathrm{CP}$ (g/day) & $17.14^{\mathrm{a}}$ & $16.39^{\mathrm{ab}}$ & $15.65^{\mathrm{bc}}$ & $14.88^{\mathrm{c}}$ & 0.22 \\
\hline $\mathrm{DCP}$ (g/day) & $12.36^{\mathrm{a}}$ & $12.32^{\mathrm{a}}$ & $11.75^{\mathrm{b}}$ & $11.34^{\mathrm{b}}$ & 0.13 \\
\hline DE (Kcal/day) & $303^{\mathrm{a}}$ & $304^{\mathrm{a}}$ & $293^{\mathrm{b}}$ & $287^{\mathrm{b}}$ & 2.17 \\
\hline
\end{tabular}

$a, b, c, d$ : Values in the same row with different superscripts differ significantly $(P<0.05)$.

$T 1=$ Control,$T 2=5.48 \%$ Moringa oleifera dry leaves, $T 3=10.97 \%$ Moringa oleifera dry leaves and $T 4=16.45 \%$ Moringa oleifera dry leaves.

\section{Growth performance:}

Data presented in Table (7) revealed that final body weight, total and daily weight gain and growth performance index $(\mathrm{GPI})$ significantly $(\mathrm{P}<0.05)$ increased with increasing the level of MDL supplement. Moringa oleifera dry leaves supplement resulted in significant $(\mathrm{P}<0.05)$ increase in final body weight by

Table (7): Growth performance of rabbits fed experimental rations.

\begin{tabular}{|c|c|c|c|c|c|}
\hline \multirow{2}{*}{ Item } & \multicolumn{4}{|c|}{ Treatment } & \multirow{2}{*}{ SEM } \\
\hline & $\mathrm{T} 1$ & $\mathrm{~T} 2$ & T3 & $\mathrm{T} 4$ & \\
\hline Animals No. & 10 & 10 & 10 & 10 & \\
\hline Experimental period (day) & 84 & 84 & 84 & 84 & \\
\hline Av. initial live body weight (g) & 768 & 770 & 769 & 773 & 8 \\
\hline Av. final live body weight $(\mathrm{g})$ & $2238^{\mathrm{c}}$ & $2358^{\mathrm{bc}}$ & $2436^{\mathrm{ab}}$ & $2525^{\mathrm{a}}$ & 32 \\
\hline Av. total LBW gain $(\mathrm{g})$ & $1470^{\mathrm{c}}$ & $1588^{\mathrm{bc}}$ & $1667^{\mathrm{ab}}$ & $1752^{\mathrm{a}}$ & 31 \\
\hline Av. daily weight gain (g) & $17.50^{\mathrm{c}}$ & $18.90^{\mathrm{bc}}$ & $19.85^{\mathrm{ab}}$ & $20.86^{\mathrm{a}}$ & 0.38 \\
\hline Improvement in ADWG \% & $0.00^{\mathrm{d}}$ & $8.00^{\mathrm{c}}$ & $13.43^{\mathrm{b}}$ & $19.20^{\mathrm{a}}$ & 1.14 \\
\hline Growth performance index $\%$ & $37.36^{\mathrm{d}}$ & $44.41^{\mathrm{c}}$ & $50.96^{\mathrm{b}}$ & $58.86^{\mathrm{a}}$ & 2.27 \\
\hline Improvement GPI \% & $0.00^{\mathrm{d}}$ & $7.06^{\mathrm{c}}$ & $11.60^{\mathrm{b}}$ & $21.50^{\mathrm{a}}$ & 1.21 \\
\hline
\end{tabular}

$a, b, c, d$ : Values in the same row with different superscripts differ significantly $(P<0.05)$.

$T 1=$ Control , $T 2=5.48 \%$ Moringa oleifera dry leaves, $T 3=10.97 \%$ Moringa oleifera dry leaves and $T 4=16.45 \%$ Moringa oleifera dry leaves.

120, 198 and $287 \mathrm{~g}$; total weight gain by 118,167 and $282 \mathrm{~g}$; daily weight gain by $1.40,2.35$ and $3.36 \mathrm{~g} /$ day or $8.00,13.43$ and $19.20 \%$ and growth performance index (GPI) by $7.06,11.60$ and $21.50 \%$ for T2, T3 and T4 compared to T1; respectively. The positive effect of moringa leaves on growth performance of rabbits was noticed in some previous studies (Kpodékon et al., 2008 and 2009), Nuhu (2010) stated that better growth rate may be due to protein quality and amino acids content of moringa leaves. El-Badawi et al. (2014) found that weight gain and ADG of rabbits fed 0.15 and $0.30 \%$ moringa supplemented rations were higher $(\mathrm{P}<0.05)$ than those fed $0 \%$ or $0.45 \%$ moringa rations. Ibrahim et al. $(2014)$ reported that live body 
weight change and daily weight gain of rabbits supplemented with 2 and $4 \mathrm{~g}$ moringa peregrine seeds meal/ kg diet significantly increased by 11.7 and $14.3 \%$ as compared to control group. Adeniji and Lawal (2012) replaced moringa as a protein feed instead of ground nut cake at levels 0, 20, 40, 60, 80 and $100 \%$ in rations of rabbit. They showed that weight gain values increased from the control diet up to $60 \%$ groundnut cake replaced with Moringa oleifera leaf meal and there after began to decrease.

\section{Feed conversion ratio:}

Results obtained in Table $(8)$ revealed significantly $(\mathrm{P}<0.05)$ improvements in feed conversion ratio with increasing the level of Moringa oleifera dry leaves supplement. Whereas, the amounts of DM, TDN, CP, $\mathrm{DCP}$ and DE required for producing one $\mathrm{kg}$ weight gain decreased significantly $(\mathrm{P}<0.05)$ with increasing the level of MDL supplement. The amounts of DM, TDN, CP, DCP and DE per kg gain decreased by 12.11, $7.14,11.22,8.45$ and $7.10 \%$ in $\mathrm{T} 2 ; 20.90,14.54,19.39,16.90$ and $14.75 \%$ in $\mathrm{T} 3$ and $28.86,20.41,27.55$, 23.94 and $20.54 \%$ in T4 compared to T1; respectively. Generally, the rabbits fed rations containing 20 or $30 \%$ MDL appeared to better feed conversion. Moreover, rabbits in group (4) which consumed 30\% MDL (T4) had the highest feed conversion and showed the lowest feed unit intake as DM, TDN, DCP or DE to get one $\mathrm{kg}$ gain. These results agreed with the findings of Ibrahim et al. (2014) who reported that rabbits received $4 \mathrm{~g}$ moringa peregrine seeds meal were improved feed conversion ratio. This improvement in feed conversion ratio may be due to the increase in body weight gain and the improvement in nutrients digestibility of diets. El-Badawi et al. (2014) found that feed conversion efficiency by rabbits in terms of $\mathrm{g}$ $\mathrm{DM}$ intake/ g weight gain was $(\mathrm{P}<0.05)$ better with rations contained 0.15 and $0.30 \%$ MDL than control.

Table (8): Feed conversion ratio of rabbits fed experimental rations.

\begin{tabular}{|c|c|c|c|c|c|}
\hline \multirow{2}{*}{ Item } & \multicolumn{4}{|c|}{ Treatment } & \multirow{2}{*}{ SEM } \\
\hline & $\mathrm{T} 1$ & $\mathrm{~T} 2$ & T3 & $\mathrm{T} 4$ & \\
\hline DM (kg/kg gain) & $6.03^{\mathrm{a}}$ & $5.30^{b}$ & $4.77^{\mathrm{c}}$ & $4.29^{\mathrm{d}}$ & 0.17 \\
\hline TDN (kg/kg gain) & $3.92^{\mathrm{a}}$ & $3.64^{\mathrm{ab}}$ & $3.35^{\mathrm{bc}}$ & $3.12^{\mathrm{c}}$ & 0.08 \\
\hline CP (kg/kg gain $)$ & $0.98^{\mathrm{a}}$ & $0.87^{\mathrm{b}}$ & $0.79^{c}$ & $0.71^{\mathrm{d}}$ & 0.03 \\
\hline DCP (kg/kg gain) & $0.71^{\mathrm{a}}$ & $0.65^{\mathrm{b}}$ & $0.59^{c}$ & $0.54^{\mathrm{d}}$ & 0.02 \\
\hline $\mathrm{DE}$ (Kcal/kg gain) & $17.314^{\mathrm{a}}$ & $16.084^{\mathrm{ab}}$ & $14.760^{\mathrm{bc}}$ & $13.758^{c}$ & 371 \\
\hline
\end{tabular}

$a, b, c, d$ : Values in the same row with different superscripts differ significantly $(P<0.05)$.

$T 1=$ Control,$T 2=5.48 \%$ Moringa oleifera dry leaves, $T 3=10.97 \%$ Moringa oleifera dry leaves and $T 4=16.45 \%$ Moringa oleifera dry leaves.

\section{Economic efficiency:}

Average daily feed cost significantly $(\mathrm{P}<0.05)$ increased with increasing MDL supplement level, which increased by $0.076,0.140$ and $0.194 \mathrm{LE} /$ day or $15.70,28.93$ and $40.08 \%$ for T2, T3 and T4 compared with

Table (9): Economic efficiency of rabbits fed experimental ratios.

\begin{tabular}{|c|c|c|c|c|c|}
\hline \multirow{2}{*}{ Item } & \multicolumn{4}{|c|}{ Treatment } & \multirow{2}{*}{ SEM } \\
\hline & $\mathrm{T} 1$ & $\mathrm{~T} 2$ & T3 & $\mathrm{T} 4$ & \\
\hline Av. daily feed intake, as fed (g) & $121.08^{\mathrm{a}}$ & $114.93^{\mathrm{b}}$ & $108.43^{\mathrm{c}}$ & $102.18^{\mathrm{d}}$ & 1.72 \\
\hline Av. daily feed cost (LE) & $0.484^{\mathrm{d}}$ & $0.560^{\mathrm{c}}$ & $0.624^{\mathrm{b}}$ & $0.678^{\mathrm{a}}$ & 0.041 \\
\hline Av. Daily weight gain (g) & $17.50^{\mathrm{c}}$ & $18.90^{\mathrm{bc}}$ & $19.85^{\mathrm{ab}}$ & $20.86^{\mathrm{a}}$ & 0.38 \\
\hline Feed cost $(\mathrm{LE}) / \mathrm{kg}$ gain & $27.66^{\mathrm{b}}$ & $29.63^{\mathrm{ab}}$ & $31.45^{\mathrm{ab}}$ & $32.50^{\mathrm{a}}$ & 0.36 \\
\hline Av. price of daily weight gain (LE) & $0.700^{\mathrm{c}}$ & $0.756^{\mathrm{bc}}$ & $0.794^{\mathrm{ab}}$ & $0.834^{\mathrm{a}}$ & 0.067 \\
\hline Net revenue (LE/day) & $0.216^{\mathrm{a}}$ & $0.196^{\mathrm{ab}}$ & $0.170^{\mathrm{bc}}$ & $0.156^{\mathrm{c}}$ & 0.032 \\
\hline Economic efficiency & $1.446^{\mathrm{a}}$ & $1.350^{\mathrm{ab}}$ & $1.272^{\mathrm{bc}}$ & $1.230^{\mathrm{c}}$ & 0.121 \\
\hline
\end{tabular}

$a, b, c, d$ : Values in the same row with different superscripts differ significantly $(P<0.05)$.

Prices of Moringa oleifera dry leaves was $20 \mathrm{LE} / \mathrm{kg}$, commercial rabbit diet was $4 \mathrm{LE} / \mathrm{kg}$ and live body weight gain was $40 \mathrm{LE} / \mathrm{kg}$. Prices of one kg ration were $4.000 \mathrm{LE}$ for T1, $4.877 \mathrm{LE}$ for T2, 5.755 LE for T3 and 6.636 LE for T4.

$T 1=$ Control , $T 2=5.48 \%$ Moringa oleifera dry leaves, $T 3=10.97 \%$ Moringa oleifera dry leaves and $T 4=16.45 \%$ Moringa oleifera dry leaves. 
T1; respectively (Table 9). Meanwhile, feed cost per kg gain increased significantly $(\mathrm{P}<0.05)$ with increasing MDL level. The high feeding cost of Moringa supplemented rations is due to the high price of moringa dry leaves which equals $20 \mathrm{LE} / \mathrm{kg}$ compared to $4 \mathrm{LE} / \mathrm{kg}$ commercial rabbit diet. Moreover, the price of average daily weight gain significantly $(\mathrm{P}<0.05)$ increased with increasing MDL supplement level, which increased by $0.056,0.094$ and $0.134 \mathrm{LE} /$ day or $8.00,13.43$ and $19.14 \%$ for T2, T3 and T4 compared to T1; respectively. On the other hand, net revenue as well as economic efficiency significantly $(\mathrm{P}<0.05)$ decreased with increasing MDL level. These results are illustrated with those obtained by Nuhu (2010) reported that the feed cost increased as the level of moringa leaf meal increased from 0 to $20 \%$.

\section{Carcass traits:}

Slaughter, carcass, head, tall, heart and tests weights and dressing percentage increased significantly $(\mathrm{P}<0.05)$, however, abdominal fat weight decreased significantly $(\mathrm{P}<0.05)$ with increasing the level of MDL supplementation compared with control (Table 10). The content of ether extract decreased significantly $(\mathrm{P}<0.05)$ with increasing the level of MDL supplementation compared with control. Whereas moisture content were nearly similar for the different groups. While, CP content tended to somewhat higher value with carcass of rabbit fed ration T3 and T2, with no significant differences. El-Badawi et al. (2014) reported that carcass dressing percentage, carcass traits and lean meat yield were higher $(\mathrm{P}<0.05)$ for rabbits fed 0.15 and $0.30 \%$ MDL supplemented rations than control.

Table (10): Carcass characteristics of rabbits fed experimental rations.

\begin{tabular}{|c|c|c|c|c|c|}
\hline \multirow{2}{*}{ Item } & \multicolumn{4}{|c|}{ Treatment } & \multirow{2}{*}{ SEM } \\
\hline & $\mathrm{T} 1$ & $\mathrm{~T} 2$ & T3 & $\mathrm{T} 4$ & \\
\hline Slaughter weight (g) & $2016^{b}$ & $2165^{b}$ & $2374^{\mathrm{a}}$ & $2547^{\mathrm{a}}$ & 66 \\
\hline Carcass weight (g) & $1039^{c}$ & $1157^{\mathrm{b}}$ & $1283^{\mathrm{a}}$ & $1387^{\mathrm{a}}$ & 42 \\
\hline Dressing \% & $51.53^{\mathrm{c}}$ & $53.42^{\mathrm{b}}$ & $54.03^{\mathrm{ab}}$ & $54.46^{\mathrm{a}}$ & 0.34 \\
\hline Blood (g) & 61.67 & 60.00 & 62.33 & 63.00 & 0.79 \\
\hline Skin (g) & 293 & 298 & 303 & 326 & 7 \\
\hline Full viscera (g) & 417 & 412 & 414 & 416 & 10 \\
\hline Empty viscera (g) & 153 & 145 & 167 & 164 & 5 \\
\hline Head $(g)$ & $132^{\mathrm{b}}$ & $131^{\mathrm{b}}$ & $133^{\mathrm{b}}$ & $144^{\mathrm{a}}$ & 2 \\
\hline Legs (g) & 65 & 72 & 68 & 74 & 2 \\
\hline Tall (g) & $12.1^{\mathrm{b}}$ & $16.0^{\mathrm{a}}$ & $14.1^{\mathrm{ab}}$ & $16.3^{\mathrm{a}}$ & 0.7 \\
\hline Heart (g) & $7.9^{\mathrm{b}}$ & $7.5^{\mathrm{b}}$ & $8.1^{\mathrm{b}}$ & $10.1^{\mathrm{a}}$ & 0.3 \\
\hline Kidneys (g) & $16.1^{\mathrm{a}}$ & $13.9^{\mathrm{b}}$ & $16.8^{\mathrm{a}}$ & $15.7^{\mathrm{ab}}$ & 0.4 \\
\hline Liver (g) & 80 & 72 & 81 & 80 & 2 \\
\hline Spleen (g) & $0.99^{\mathrm{b}}$ & $1.00^{\mathrm{b}}$ & $1.47^{\mathrm{a}}$ & $1.03^{\mathrm{b}}$ & 0.08 \\
\hline Lungs (g) & $13.6^{\mathrm{ab}}$ & $12,9^{\mathrm{b}}$ & $15.5^{\mathrm{a}}$ & $15.9^{\mathrm{a}}$ & 107 \\
\hline Tests (g) & $5.6^{\mathrm{b}}$ & $7.7^{\mathrm{a}}$ & $8.2^{\mathrm{a}}$ & $8.5^{\mathrm{a}}$ & 0.4 \\
\hline Abdominal fat (g) & $37.9^{\mathrm{a}}$ & $34.9^{\mathrm{a}}$ & $28.8^{\mathrm{b}}$ & $27.0^{\mathrm{b}}$ & 1.4 \\
\hline Meat composition \% & & & & & \\
\hline $\begin{array}{l}\text { Moisture } \\
\text { Protein }\end{array}$ & 72.5 & 73.9 & 73.5 & 73.2 & 2.0 \\
\hline Protein & 20.9 & 20.7 & 21.3 & 21.6 & 0.2 \\
\hline Either extract & $5.5^{\mathrm{a}}$ & $4.3^{b}$ & $4.2^{\mathrm{b}}$ & $4.2^{\mathrm{b}}$ & 0.2 \\
\hline Ash & 1.1 & 1.1 & 1.0 & 1.0 & 0.02 \\
\hline
\end{tabular}

$a, b, c$ : Values in the same row with different superscripts differ significantly $(P<0.05)$.

$T 1=$ Control , $T 2=5.48 \%$ Moringa oleifera dry leaves, $T 3=10.97 \%$ Moringa oleifera dry leaves and $T 4=16.45 \%$ Moringa oleifera dry leaves.

\section{CONCLUSION}

From these results, it could be concluded that introducing 16.45\% Moringa oleifera dry leaves in rabbit's diet to cover $30 \%$ of commercial rabbit diet protein tended to higher digestibility coefficients for most nutrients, increased nutritive value as TDN and DCP as well as increased daily gain. Moreover, this 
level of MDL improved feed efficiency and the prices of LBW gain. At the same time, dressing percentage appeared to higher.

\section{REFERENCES}

Adeniji, A.A. and M. Lawal (2012). Effects of replacing groundnut cake with Moringa oleifera leaf meal in the diets of grower rabbits. International Journal of Molecular Veterinary Research, 2(3): 8-13.

AOAC (1995). Association of Official Analytical Chemists, 16th ed. Official Methods of Analysis, Washington, DC, USA.

Booth, F.E. and G.E. Wickens (1988). Non-timber uses of selected arid zone trees and shrubs in Africa. FAO conservation Guide, pp: 92-101, Rome.

Chinwe, C. and N. Isitua (2010). Studies on the hematological impact of Moringa oleifera in rabbits. A poster presented at $2^{\text {nd }}$ International Conference on Applied Biotechnology, Khartoum, Sudan.

Dorga, P.; D. Sngh and S. Tandon (1975). Vitamin content in moringa. J. Current Sci., 44: 30-31.

Duncan, D. B. (1955). Multiple Range and Multiple F Tests. Biometrics, 11:1.

El-Badawi, A.Y.; H.A.A. Omer; A.A. Abedo and M.H.M. Yacout (2014). Response of growing New Zealand White rabbits to rations supplemented with different levels of Moringa oleifera dry leaves. Global Veterinaria, 12 (4): 573-582.

El-Esawy, Ghada S. M. (2015). Effect of supplementing different levels of Moringa oleifera plant leaves on productive performance of dairy cows. Ph.D. Thesis, Fac. of Agric., Kaferlsheikh University.

IBM SPSS Statistics (2014). Statistical package for the social sciences, Release 22, SPSS INC, Chicago, USA.

Ibrahim, N.H.; A.S. Morsy and M.E. Ashgan (2014). Effect of moringa peregrine seeds on productive performance and hemato-biochemical parameters of growing rabbits. J. Am. Sci., 10(6):7-12.

Jaiswall, D.; P. Kumar Rai; A. Kumar; S. Mehta and G.Watal (2009). Effect of Moringa oleifera lam. Leaves aqueous extract therapy on hyperglycemic rats. J. Ethnopharmacol., 123(3): 392-396.

Kakengi, A.M.V.; M.N. Shen; S.V. Sarwart and T. Fujihara (2003). Can Moringa oleifera be used as protein supplement to ruminant diet? Asian- Australian Journal of Animal Science, 18(1): 42-47.

Kpodékon, T.M.; A.K.I. Youssao; C.M. Tossou; A.Y. Djago and P. Coudert (2008). Effects of molasses incorporation in rabbit fattening diet on growth performances. $9^{\text {th }}$ World Rabbit Congress, June 10-13, Verona-Italy, pp: 123-125.

Kpodékon, M.; A.K.I. Youssao; G.B. Koutinhouin; I.L. Baba; J.M. Dessou and Y. Djago (2009). Effect de la granulation sur les performances de croissance l'efficacité alimentaire et la viabilité des lapereaux en condition d'élevage tropical Revue Élev. Méd. Vét. Pays trop., 62(1): 75-80.

Khalel, M. S.; A. M. Shwerab; A. A. Hassan; M. H. Yacout; A. Y. El-Badawi and Mona S. Zaki (2014). Nutritional evaluation of moringa oleifera fodder in comparison with Trifolium alexandrinum (berseem) and impact of feeding on lactation performance of cows. Life Sci. J., 11(10):1040-1054.

May, R.W. and J.M. Bell (1971). Digestible and metabolizable energy values of some feeds for the growing pig. Can. J. Anim. Sci., 51: 271-278.

Moyo, B.; P.J. Masika; A. Hugo and V. Muchenje (2011). Nutritional characterization of moringa (Moringa oleifera) leaves. Africa. J. of Biotechnology, 10(60): 12925-12933. 


\section{Omara et al.}

Musa Azara, S. I.; M. Jibrin; D. I. Hassan and A. Yakubu (2014). Effects of oral administration of Moringa oleifera seed on blood chemistry and reproductive performance of female rabbits. Int. J. Agric.Sci. and Vet. Med., 2(1): 18-21.

North, M.O. (1981). Commercial chicken production. Annual. 2nd Edition. Av. Publishing company I. N. C., West-post Connecticut. USA.

NRC (1977). Nutrients Requirements of Domestic Animals. Nutrients Requirements of Rabbits. $2^{\text {nd }}$ Edition. National Research Council, National Academy of Science. Washington, DC. USA.

Nuhu, F. (2010). Effect of moringa leaf meal (MOLM) on nutrient digestibility, growth, carcass and blood indices of weaner rabbits. MSc, Faculty of Agriculture and Natural Resources, Kwame Nkrumah University of Science and Technology, Kumasi, Ghana.

Odeyinka, S.M.; O.J. Oyedele; T.O. Adeleke and J.A. Odedire (2008). Productive performance of rabbits fed Moringa oleifera as a replacement for centrosema pubescens. 9th World Rabbit Congress - June 10-13Verona - Italy, 411-415.

Oduro, I.; W.O. Ellis and D. Owusu (2008). Nutritional potential of two leafy vegetables: Moringa Oleifera and Impomea batatas leaves. Scientific research and essay, 3(2): 57-60.

Olatunji, A. K.; O. J. Alagbe and M. A. Hammed (2013). Effect of varying Levels of Moringa olifera leaf meal on performance and blood profile of weaner rabbits. International Journal of Science and Research (IJSR), 5(6): 803-806.

Onu, P.N. and A.O. Aniebo (2011). Influence of Moringa oleifera leaf meal on the performance and blood chemistry of starter broilers. International Journal of Food, Agriculture and Veterinary Sciences, 1(1): $38-44$.

Osman, H.M.; M.E. Shayoub and E.M. Babiker (2012). The effect of Moringa oleifera leaves on blood parameters and body weights of Albino rats and rabbits. Jordan J. of Biological Sci., 5(3): 147-150.

Safwat, A.M.; L. Sarmiento-Franco; R. Santos-Ricalde and D. Nieves (2014). Effect of dietary inclusion of Leucaena leucocephala or Moringa oleifera leaf meal on performance of growing rabbits. Trop. Anim. Health Prod., 46:1193-1198.

Sreelather, S. and P.R. Padma (2009). Antioxidant activity and total phenolic content of Moringa oleifera leaves in two stages of maturity. J. Plant Food Human Nutri, 64: 303-311.

Warner, A.C.I. (1964). Production of volatile fatty acids in the rumen, method of measurements. Nut. Abst. and Rev., 34: 339. 


\title{
تأثير اضافة مستويات مختلفة من أوراق المورينجا الجافة فى علائق الأرانب على أدائها الانتاجى
}

\author{
محمد عيسى عمارة، غادة صلاح العيسوى، واصف عبدالعزيز رياض، عبدالحليم محمد عبدالسلام محى الدين \\ معهل بحوث الاتتاج الحيوانس، مركز البحوث الزراعية، الدقى، الجبزة
}

استخدم فى هذه الدر اسة 40 ذكر أرنب نيوزيلاندى أبيض عمر 7 أسابيع ومتوسط وزنها 772\$ 8ـ جم فى التصميم كامل العشو ائية

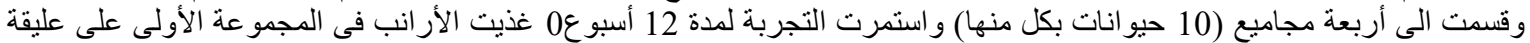

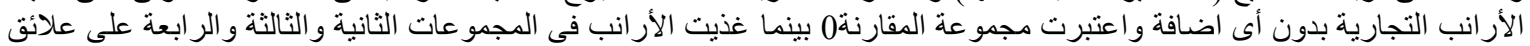

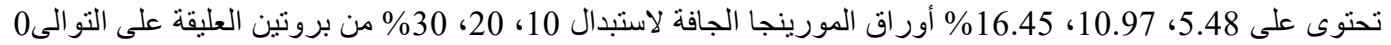

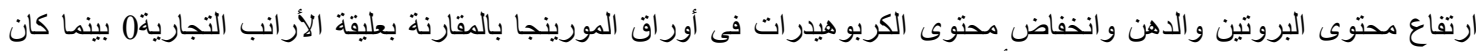

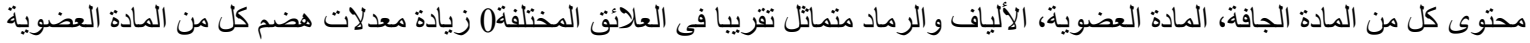

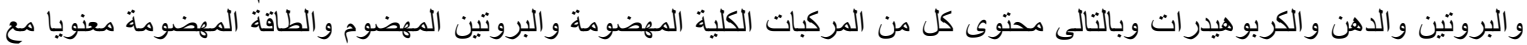

زيادة مستوى أور اق المورينجا

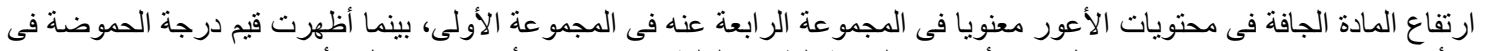

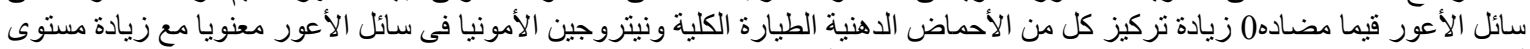

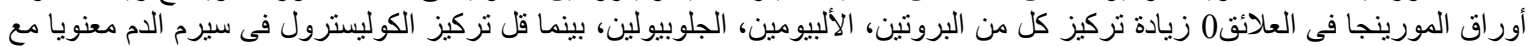

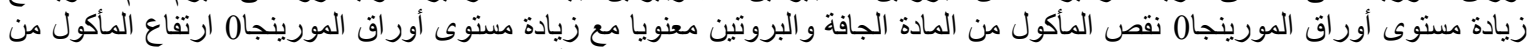

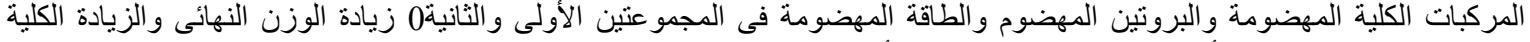

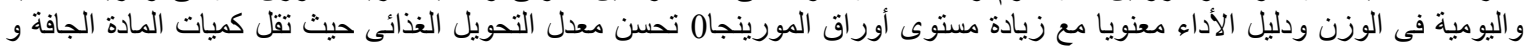

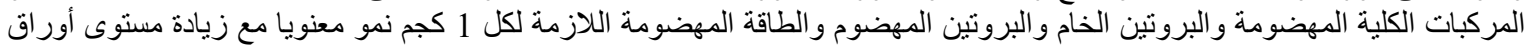

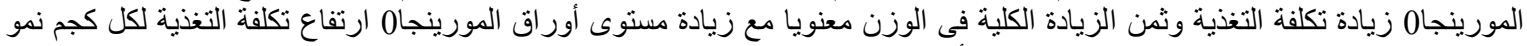

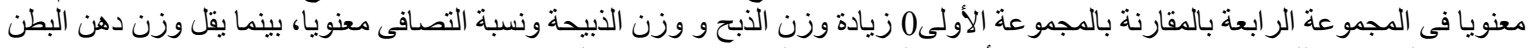

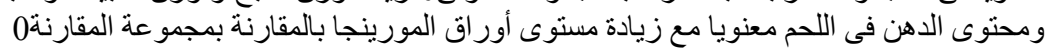

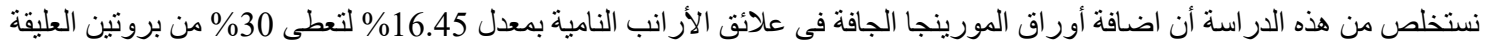

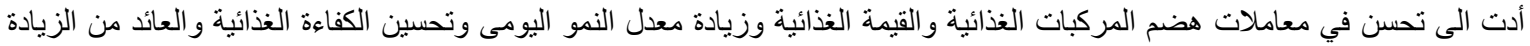

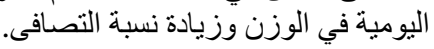

